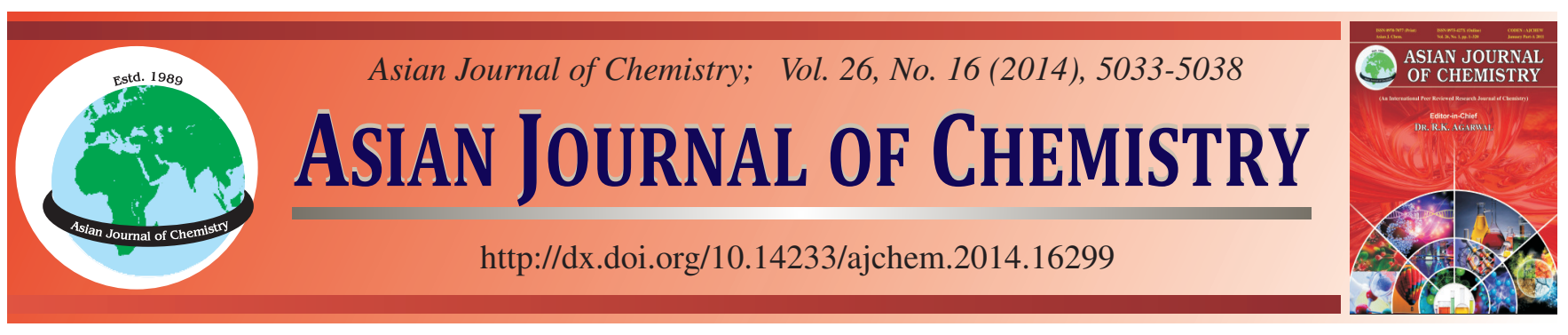

\title{
Synthesis of Biogasoline from Used Palm Cooking Oil Through Catalytic Hydrocracking by Using Cr-Activated Natural Zeolite as Catalyst
}

\author{
Jujarama $^{1}$, Karna Wijaya ${ }^{2, *}$, Mohammad ShidiQ ${ }^{3}$, Mohammad Fahrurrozi $^{3}$ and Suheryanto $^{4}$
}

\begin{abstract}
${ }^{1}$ Magister of Engineering System, Faculty of Engineering, Gadjah Mada University, Yogyakarta, Indonesia ${ }^{2}$ Chemistry Department, Faculty of Mathematics and Natural Sciences, Gadjah Mada University, Yogyakarta, Indonesia ${ }^{3}$ Chemical Engineering Department, Faculty of Engineering, Gadjah Mada University, Yogyakarta, Indonesia

${ }^{4}$ Chemistry Department, Faculty of Mathematics and Natural Sciences, Sriwijaya University, Indralaya, South Sumatera, Indonesia
\end{abstract}

*Corresponding author: karna_ugm@yahoo.com, karnawijaya@ugm.ac.id

\begin{abstract}
This study was concerning on production of biogasoline from used palm cooking oil through Cr-activated natural zeolite catalyzed hydrocracking. Natural zeolite was activated using $6 \mathrm{M}$ hydrochloric acid. The precursor $\mathrm{Cr}\left(\mathrm{NO}_{3}\right)_{3} \cdot 9 \mathrm{H}_{2} \mathrm{O}$ was impregnated on activated natural zeolite. Catalysts characterization including catalysts crystallinity using X-ray diffraction and catalysts porosity using the BET method. The used palm cooking oil was vaporized at $350{ }^{\circ} \mathrm{C}$ and then flowed into the batch reactor which temperature was set at 400,450 and $500{ }^{\circ} \mathrm{C}$. Hydrogen was feed into the batch reactor at a constant rate of $40 \mathrm{~mL} / \mathrm{min}$. The variation of reactor conditions was with no catalysts, with zeolite catalysts and with catalyst Cr-activated natural zeolite. The product was then condensed in a water cooled condensor. The condensed products was analyzed using GC, GC-MS, ASTM D 1298, ASTM D 130, ASTM D 323 and ASTM D 86/99a to determine the formed fraction. The results show that the acid activation and impregnation reaction at zeolite samples can improve it crystallinity, surface area and pore radius. Active natural zeolite sample has a specific surface area of $43.815 \mathrm{~m}^{2} / \mathrm{g}$ while Cr-activated natural zeolite has a specific surface area of $89.514 \mathrm{~m}^{2} / \mathrm{g}$. The highest conversion was gained by using Cr-activated natural zeolite catalysts at $500{ }^{\circ} \mathrm{C}$ reactor temperature which produced $76.44 \%$ liquid product and $23.25 \%$ yield
\end{abstract}

Keywords: Biogasoline, Used palm cooking oil, Catalysts, Cr-activated natural zeolite, Hydrocracking.

\section{INTRODUCTION}

The limitation of fossil fuel energy and the increasing necessity of fuel has been motivating scientists on finding alternative energy as a subtituent of fossil fuel and natural gas which has renewable and environmental friendly properties. The inclined increasing price of fossil fuel and the high dependable on fossil fuel is one of the fundamental reason in order to reach an alternative energy. Indonesia, known as oil producer, is finally becoming nett importer of fuel because its nation necessity and demand on oil is higher than its production. In line with the decreasing natural resources on fossil fuel and also the increasing price of raw fuel around the world, scientist has been developing and searching an alternative energy as subtituent of fossil fuel ${ }^{1-5}$.

Renewable energy sources beneficial become solution in order to fulfill the higher number energy necessity in the future time. The research development on fuel production using crude palm oil has been attracting many scientist and researcher. Cracking process becomes the most interesting method because the method is relatively easier and low cost. The most dominant content on fatty acid in crude palm oil is palmitic acid having unbonding 16 carbon atom and oleic acid having 18 carbon atom with one double bond in the center of its structure. Fatty acids bonded on triglceride structure on crude palm oil can be changed into biogasoline $\left(\mathrm{C}_{16}-\mathrm{C}_{12}\right)$ or other fuel through chain carbon breaking process on fatty acid, so that through crude palm oil can be be produced derivatives products similar with fossil fuel process result such as diesel fuel, kerosene or gasoline $^{2-5}$.

Indonesian commonly use the crude palm oil as frying oil. Used frying oil occurs structure changing that produce carcinogenic content. As the result, many restaurants and food courts used to throw away the used frying oil to keep their food quality. On the contrary, they are also many restaurants or food courts used frying oil in lower price. The usage of the used frying oil can give negative impact on health. This case can be anticipated through managing those used frying oil by converting them into biogasoline so that it can be increasing its value. Cracking is commonly a process on which big molecule has broken into smaller size. Cracking is a process to crack long chain hydrocarbon into smaller hydrocarbon through the 
catalyst and hydrogen present. Hydrocarbon molecule cracking mechanism contains of $\mathrm{C}-\mathrm{C}$ bonding breaking. Based on Gates (1979), hydrocarbon catalytic cracking is predicted through linking material that is carbonium ion known as carbocation formed through the breaking process $\mathrm{C}-\mathrm{H}$ bonding from its hydrocarbon molecule. Cracking reaction is predicted through 3 steps reaction i.e. initiation process, propagation process and termination process ${ }^{4-9}$.

Zeolite is porous silica-alumina crystal, containing alumina group and silica group on which each material has tetrahedral form and connected with oxygen atom so that it has 3 dimensions backbone. Zeolite is solid on which has wide range surface because its solid shape has many pores. The higher and the bigger porous, the wider its solid surface. Porous on its solid carrying agent that can catch metal particle so that they can be trapped. Through the process, it is hopefully all of the surfaces as carrying agent, either in outer or inlet surface can be shielded by metal catalyst ${ }^{7-12}$.

The research aim is to study the production of biogasoline from used palm oil through hydrocracking process on $\mathrm{Cr}$ activated natural zeolite catalyst. Furthermore, it aims also to study the effectiveness of crude palm oil cracking process using Cr-activated natural zeolite catalyst.

\section{EXPERIMENTAL}

Materials that were used are aquadest, used palm oil, $6 \mathrm{M}$ $\mathrm{HCl}$, natural zeolite, chromium nitrate nonahydrate $\mathrm{Cr}\left(\mathrm{NO}_{3}\right)_{3} \cdot 9 \mathrm{H}_{2} \mathrm{O}$ as chromium source, hydrogen gas, nitrogen gas. This research were using many tools such as cracking reactor equipped with condenser, oxidation tools, beaker glasses, evaporating dish, buchner filter, vacuum pump, magnetic stirrer, 100 mesh filter, digital weight, oven, furnace, hot plate stirrer. Instrument for material characteristic that were used are X-ray difractometer, IR spectrofometer, atomic absorbtion spectrophotometer, gas chromatography-mass spectroscopy.

Natural zeolite preparation: Zeolite was washed twice using aquadest then submerged for $3 \times 24 \mathrm{~h}$. After that it was filtered and dried in oven for $12 \mathrm{~h}$ on $120^{\circ} \mathrm{C}$. Dried zeolite were grinded and filtered using 100 mesh. The result was labeled as natural zeolite. $300 \mathrm{~g}$ of 100 mesh zeolite, was refluxed on $6 \mathrm{M} \mathrm{HCl}$ (comparison 1:2) for $0.5 \mathrm{~h}$ on $90^{\circ} \mathrm{C}$ strring using stirrer. Refluxed zeolite was washed using aquadest on $\mathrm{pH}$ 6. After that it was dried on $120^{\circ} \mathrm{C}$ for $2 \mathrm{~h}$ in oven. The result was labeled as natural active zeolite.

Chromium metal impregnation: Chromium metal impregnation $(\mathrm{Cr} 1 \%(\mathrm{~b} / \mathrm{b}))$ on zeolite surface uses wet impregnation. 300 grams of active natural zeolite was submerged using $\mathrm{Cr}\left(\mathrm{NO}_{3}\right)_{3} \cdot 9 \mathrm{H}_{2} \mathrm{O} 0,05 \mathrm{M}$ and stirred for $5 \mathrm{~h}$ on $80-90{ }^{\circ} \mathrm{C}$. Resulted solution was filtered and heated using oven for $2 \mathrm{~h}$ on $120^{\circ} \mathrm{C}$.
Calcination process was done on $500{ }^{\circ} \mathrm{C}$ for $2 \mathrm{~h}$ using $\mathrm{N}_{2}$ gas flow. Gas flow rate on calcinations process was $25 \mathrm{~mL} / \mathrm{min}$. The formed catalyst was inserted on furnace tube for reducing process using $\mathrm{H}_{2}$ gas set on $15 \mathrm{~mL} / \mathrm{min}$ for $1,5 \mathrm{~h}$ on $400{ }^{\circ} \mathrm{C}$. $\mathrm{Cr}$ content that was absorbed on solid phase was analyzed using AAS method. Cr-activated natural zeolite was analyzed using $\mathrm{X}$-ray Diffraction and BET for qualitative analysis.

Used plam cooking oil catalytic cracking: $500 \mathrm{~mL}$ used palm cooking oil was set on feeder column on which had been set on upside of catalytic reactor. Cracking processes were set for 4 conditions i.e. condition with no catalyst and hydrogen, with no catalyst, with natural zeolite and with Cr-activated natural zeolite. Using zeolite or Cr-activated natural zeolite catalyst, it was placed for $50 \mathrm{~g}$. Feeder column was set on $350{ }^{\circ} \mathrm{C}$ further the reactor was heated on different temperature i.e. $400,450500{ }^{\circ} \mathrm{C}$ using $\mathrm{H}_{2}$ gas flow $40 \mathrm{~mL} / \mathrm{min}$. Cracking result was condensed using cooler and the resulted product was distilled on $100-150{ }^{\circ} \mathrm{C}$ in order to get the main product. Furthermore, it was characterized using GC-MS and ASTM method.

\section{RESULTS AND DISCUSSION}

Crystallinity test for catalyst: Crystallinity test for natural zeolite catalyst and Cr-natural activated natural zeolite used $\mathrm{X}$-ray diffraction (XRD) in order to study the effect of Cr metal on natural zeolite. Solid analysis result of X-ray diffraction for natural zeolite, acid activated (H)-natural zeolite and $\mathrm{Cr}$ activated natural zeolite could be seen on Fig. 1.

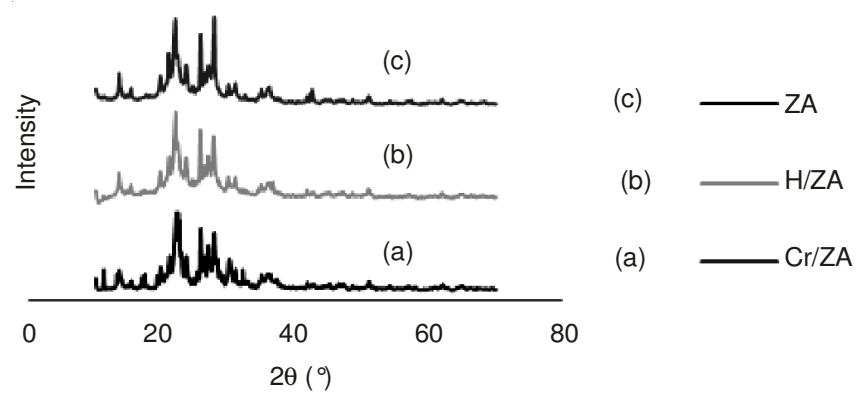

Fig. 1. Diffractogram for natural zeolite, acid activated $(\mathrm{H})$ natural zeolite catalyst and $\mathrm{Cr}$-activated natural zeolite

The figure was shown that the addition of $\mathrm{Cr}$ metal on natural zeolite was not changing the natural zeolite crystal structure. It could be shown from natural zeolite $2 \theta$ peak that occurred. Standard natural zeolite has 5 main peaks of $2 \theta$ : $13,48^{\circ} ; 21,93^{\circ} ; 23,48^{\circ}, 25,69^{\circ}$, dan $27,74^{\circ}$ on which those peaks could be still shown on acid activated $(\mathrm{H})$-natural zeolite and $\mathrm{Cr}$-activated natural zeolite (Table-1). Metal on solid phase was commonly forming crystal oxide so that it could change

\begin{tabular}{cc|cc|c}
\hline \multicolumn{5}{c}{ TABLE-1 } \\
\multicolumn{2}{|c|}{ INTENSITIES OF FIVE MAIN PEAKS OF XRD OF CATALYST } \\
\hline \multicolumn{2}{c|}{ Natural zeolite } & Acid activated (H)-natural zeolite & Cr-activated natural zeolite \\
\hline $2 \theta(\mathrm{deg})$ & Intensity (Count) & $2 \theta(\mathrm{deg})$ & Intensity (Count) & $2 \theta$ (deg) \\
\hline 13,4821 & 2320 & 13,4821 & 2577 & 13,4821 \\
21,9388 & 6219 & 21,9388 & 7190 & 16,1512 \\
23,4864 & 2768 & 23,4864 & 3746 & 23,4864 \\
25,6972 & 5398 & 25,6420 & 5826 & 25,6972 \\
27,7423 & 5098 & 27,6318 & 5351 & 27,7423 \\
\hline
\end{tabular}


its intensity when it was submerged. It could appear because metal existence could contribute for catalyst crystal value.

Crystallinity increasing on activated zeolite using $\mathrm{HCl} 6 \mathrm{M}$ was caused by impurities loss on natural zeolite so that bonding backbond on zeolite tetrahedral structure has becoming more similar and neat. The similar case was also happened for natural zeolite supported on $\mathrm{Cr}$ metal. The increasing intenstity has shown that there are also increasing on its crystallinity. It is because calcinations process after impregnation causing those organic impurities on zeolite was aparted and also the formation of metal compound and metal oxide on which are stable and rigid.

Surface area, average pore radius and total pore volume: The result of surface area, porous diameter average and catalyst porous volume for acid activated $(\mathrm{H})$-natural zeolite and $\mathrm{Cr}-$ activated natural zeolite using BET method was shown on Table-2.

\begin{tabular}{|c|c|c|c|}
\hline \multicolumn{4}{|c|}{$\begin{array}{l}\text { TABLE-2 } \\
\text { SURFACE AREA, AVERAGE PORE RADIUS AND } \\
\text { TOTAL PORE VOLUME FOR ACID ACTIVATED } \\
\text { (H)-NATURAL ZEOLITE AND CR-ACTIVATED } \\
\text { NATURAL ZEOLITE USING BET METHOD }\end{array}$} \\
\hline Catalyst & $\begin{array}{c}\text { Specific } \\
\text { surface area } \\
\left(\mathrm{m}^{2} / \mathrm{g}\right)\end{array}$ & $\begin{array}{c}\text { Average } \\
\text { pore } \\
\text { radius }(\AA)\end{array}$ & $\begin{array}{c}\text { Total pore } \\
\text { volume } \\
\text { (cc/g) }\end{array}$ \\
\hline Natural zeolite & 18.02 & 9.69 & 8.73 \\
\hline Acid activated (H)-zeolite & 43,82 & 4.82 & 1.06 \\
\hline $\mathrm{Cr}$-activated natural zeolite & 89.51 & 7.63 & 3.42 \\
\hline
\end{tabular}

The result has shown that Cr-activated natural zeolite catalyst has surface area wider besides porous diameter average and porous volume total is smaller than natural zeolite catalyst. It was caused by supported $\mathrm{Cr}$ metal on surface of catalyst would increase its specific surface area, $\mathrm{Cr}$ metal that had been added into zeolite would patch on porous surface neatly so that total of porous volume would be decreasing. Porous diameter average on natural zeolite would be decreasing after it had supported on Cr metal, it caused by metal existence that patched on zeolite porous on which would be covering zeolite porous. The highest size of triglyceride was $1,5 \mathrm{~nm}(15 \AA)$ and The smallest size was $12 \mu \mathrm{m}$ so that hydrocracking reaction on triglyceride would be only happened on surface of $\mathrm{Cr}$ activated natural zeolite catalyst. The smaller porous diameter average was expected to select small or lighter molecule as gasoline fraction. Through this catalyst characteristic result was expected that using $\mathrm{Cr}$-activated natural zeolite would be more selective and optimal on used palm oil cracking for gasoline fraction.

Catalyst activity test: Used palm oil hydrocracking process using catalyst was done by using $500 \mathrm{~mL}$-feed/catalyst ratio 10/1 and hydrogen flow rate of $40 \mathrm{~mL} / \mathrm{min}$ with temperature variation: 400,450 and $500{ }^{\circ} \mathrm{C}$. Chromium metal docking into natural activated zeolite was done by using atomic absorption spectroscopy and $\mathrm{Cr}$ metal content was $0.53 \%$. Catalyst activity can be seen through the conversion factor of used palm oil resulted into liquid product. The distribution of used palm oil hydrocracking process can be seen on Table-3

Hydrocracking composition on reactor condition comparison shown in Fig. 2 which reveal the catalyst activity working on feed conversion of used palm oil.

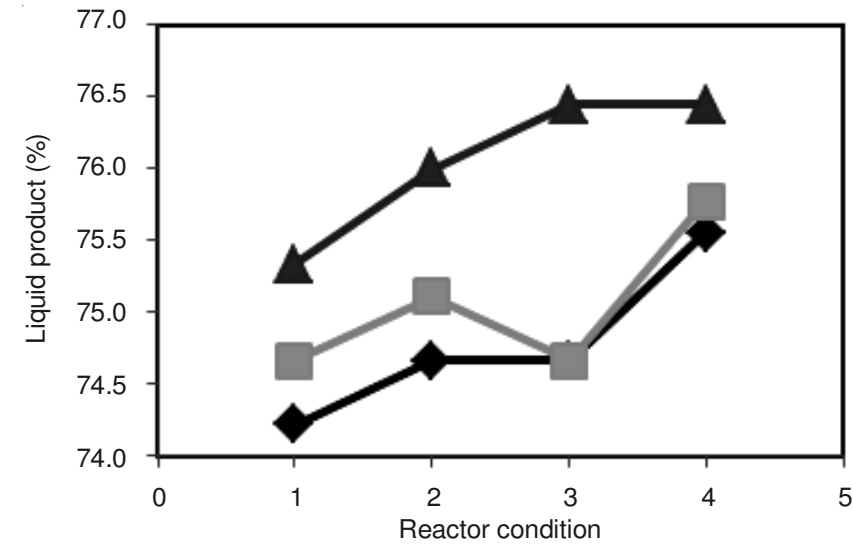

Fig. 2. Graph of reactor condition comparison versus liquid product on various temperature (1) no catalyst and hydrogen flow, (2) no catalyst, (3) natural zeolite, (4) Cr-activated natural zeolite

The graph has shown that Cr-activated natural zeolite catalyst has the higher catalyst activity compared with natural zeolite catalyst and without catalyst with the highest liquid product conversion on each temperature. It was caused by the effect of $\mathrm{Cr}$ metal docked into natural activated zeolite catalyst on which has ability to increase specific surface area so that the active site could be more optimal in order to catalyze the hydrocracking process. Chromium metal has forming and cutting off the bonding caused by the existence of the half lower energy of orbital. The electron valence on $d$ orbital

\begin{tabular}{cccccc}
\multicolumn{7}{c}{ TABEL-3 } \\
PRODUCT DISTRIBUTION OF USED PALM OIL HYDROCRACKING PROCESS \\
\hline Catalysts & $\mathrm{H}_{2}$ Flow $(\mathrm{mL} / \mathrm{min})$ & Temp $\left({ }^{\circ} \mathrm{C}\right)$ & Liquid Product $(\% \mathrm{~b} / \mathrm{b})$ & Residue $(\% \mathrm{~b} / \mathrm{b})$ & Gas Product $(\% \mathrm{~b} / \mathrm{b})$ \\
\hline- & 0 & 400 & 74,22 & 8,89 & 16,88 \\
- & 0 & 450 & 74,66 & 8,22 & 17,11 \\
- & 0 & 500 & 75,33 & 9,33 & 15,33 \\
- & 40 & 400 & 74,66 & 9,56 & 15,77 \\
- & 40 & 450 & 75,11 & 9,78 & 15,11 \\
Natural zeolite & 40 & 500 & 76,00 & 9,33 & 14,67 \\
Natural zeolite & 40 & 400 & 74,66 & 8,89 & 14,44 \\
Natural zeolite & 40 & 450 & 74,66 & 8,44 & 16,44 \\
Cr-activated natural zeolite & 40 & 500 & 76,44 & 10,67 & 15,11 \\
Cr-activated natural zeolite & 40 & 400 & 75,55 & 10,44 & 13,78 \\
Cr-activated natural zeolite & 40 & 450 & 75,77 & 8,67 & 13,78 \\
\hline
\end{tabular}


connected with $s$ and $p$ electron on which gave availability a low energy electronic condition on high amount and it was an ideal condition for catalytic reaction. It can be conclude that $\mathrm{Cr}$-activated natural zeoite has higher catalyst activity rather than natural zeolite or without catalyst in order to convert used palm oil on hydrocracking reaction.

Catalyst selectivity test and the effect of temperature in hydrocracking reaction: Liquid product of hydrocracking was predicted consist of hydrocarbon compound on which has less 18 carbon chains forming stable compound. Hydrocracking process was analyzed using reactor on 400, 450 and $500{ }^{\circ} \mathrm{C}$. The resulted gas coming from hydrocracking reaction was condensed to produce liquid fraction.

At the end of condensation product, it resulted blackist brown and strictly odor that was the product of hydrocracking process. Liquid product as a result of catalytic activity test on used palm oil hydrocracking for various temperature were analyzed using gas chromatography. It aims to know the amount of conversion result fraction of liquid product of used palm oil. This can be calculated based on large area of chromatogram where gasoline fraction occurs on 0-10 min retention time meanwhile diesel fraction occurs on 10-20 min retention time.

The chromatogram of liquid product of hydrocracking on 400,450 and $500{ }^{\circ} \mathrm{C}$ are shown in Figs. 3-5.
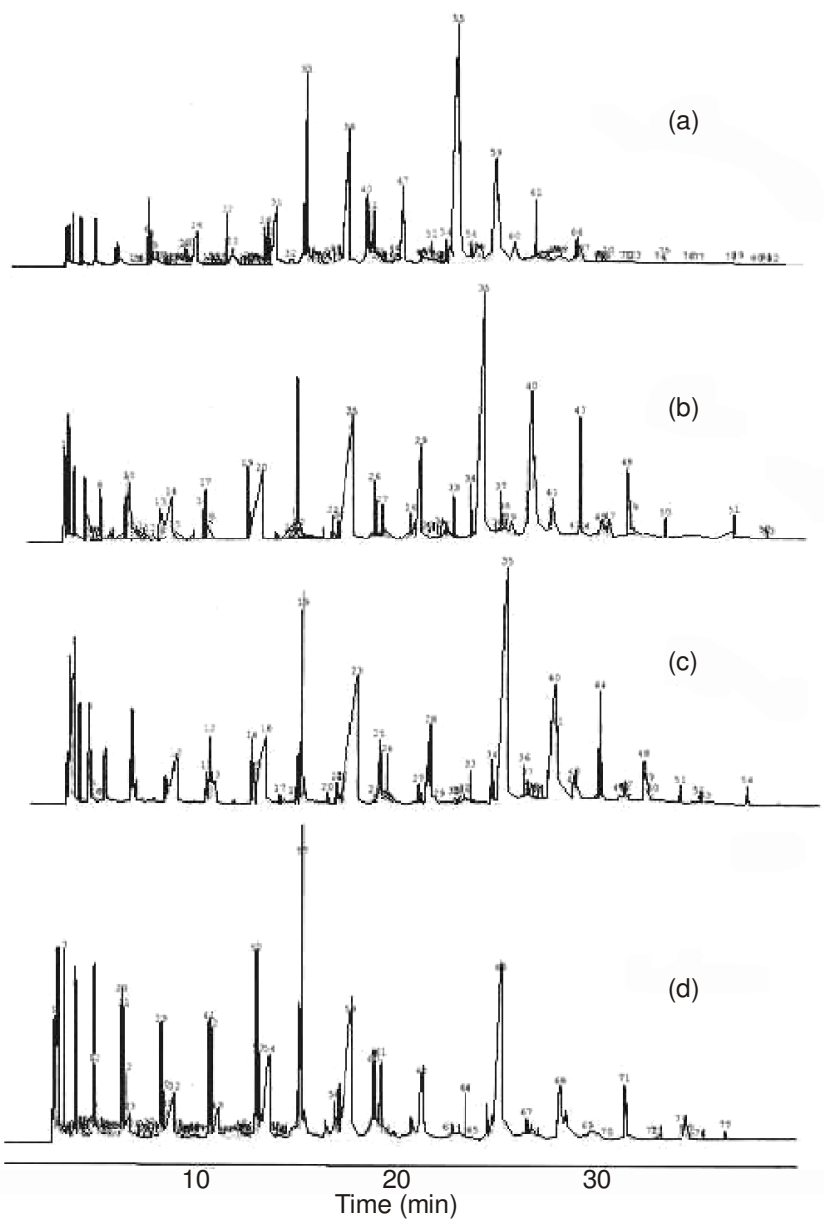

Fig. 3. Chromatogram of liquid product of used palm oil hydrocracking on $400{ }^{\circ} \mathrm{C}$ for condition (a) with no catalyst and hydrogen (b) with no catalyst (c) with natural zeolite (d) with Cr-activated natural zeolite
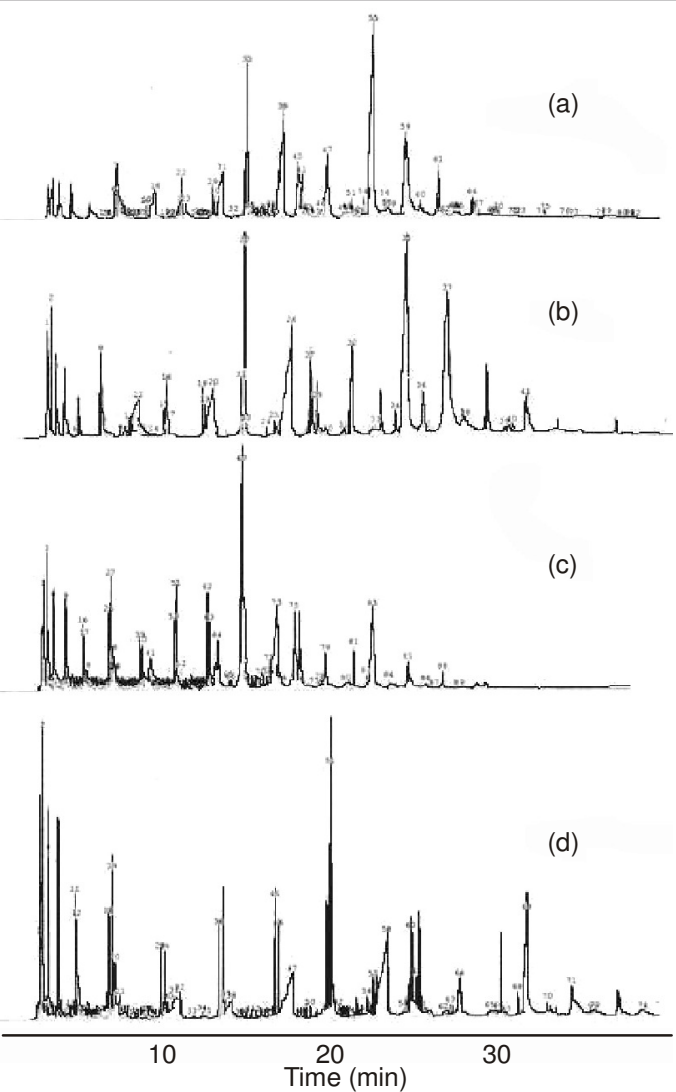

Fig. 4. Chromatogram of liquid product of used palm oil hydrocracking on $450{ }^{\circ} \mathrm{C}$ for condition (a) with no catalyst and hydrogen (b) with no catalyst (c) with natural zeolite (d) with Cr-activated natural zeolite

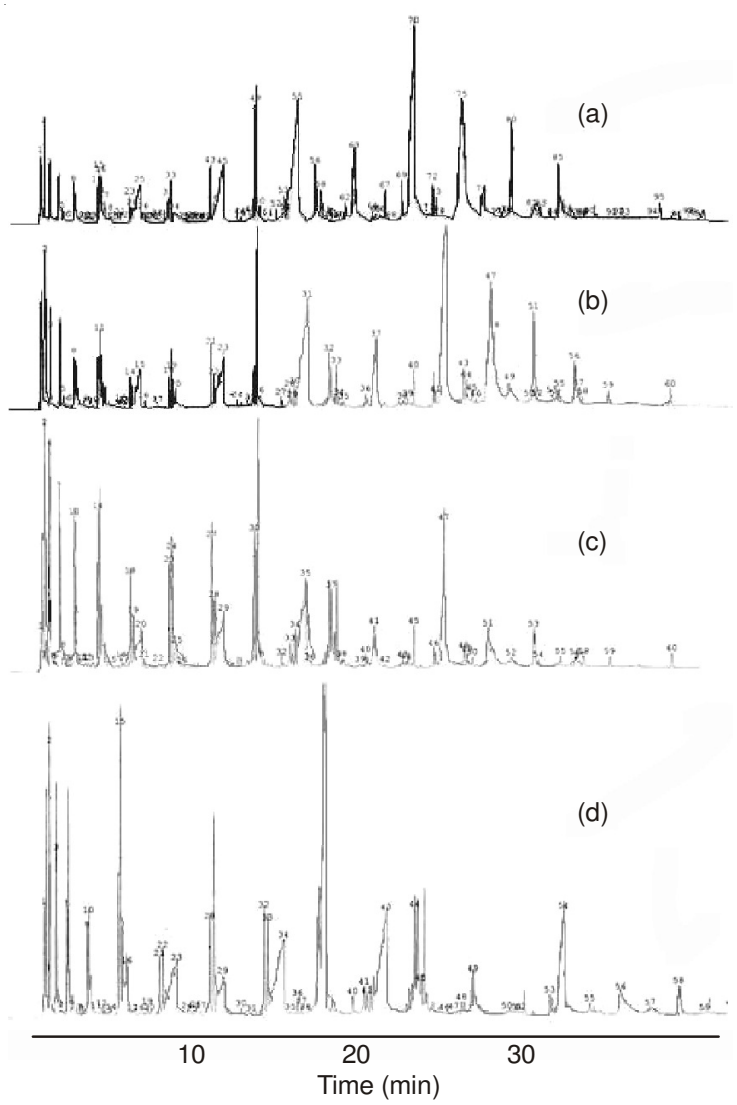

Fig. 5. Chromatogram of liquid product of used palm oil hydrocracking on $500{ }^{\circ} \mathrm{C}$ for condition (a) with no catalyst and hydrogen (b) with no catalyst (c) with natural zeolite (d) with Cr-activated natural zeolite 
Hydrocracking process using catalyst aims to break down long saturated carbon chain, cyclic or non-cyclic so that it produce carbon chain on lower weight molecule. The function of catalyst usage on hydrocracking reaction is its activity and selectivity. Catalyst activity is stated as catalyst performance on conversion of the total of used palm oil resulting on liquid product, gas product or coke. While the catalyst selectivity is stated as catalyst performance resulting on liquid product on which are having a tendency to form gasoline fraction, diesel or heavy oil. Based on the result of liquid product chromatogram of hydrocracking result of used palm oil shown that each catalyst different selectivity, It can be seen on different peaks formed on chromatogram. Specific peaks chromatogram noted as the product on gasoline fraction, or heavy oil. Catalyst selectivity on the fractions is based on the chromatogram large area. The highest amount of biogasoline fraction qualitatively can be obtained on reactor condition using catalyst $\mathrm{Cr}$-activated natural zeolite on $500{ }^{\circ} \mathrm{C}$. Liquid product of its condition was done further using distillation process on $150{ }^{\circ} \mathrm{C}$ in order to get the biogasoline fraction.

GC-MS analysis: GC-MS analysis is used to find the suitability ranges for peak biogasoline products produced with commercial gasoline. GC-MS QP2010S Shimadzu with Rastek Rxi-5MS colomn and 30 meter of its length using helium gas carrier is used for the research. From the results of the analysis contained 11 peaks with a large area that is above $4 \%$ (Table- 4 ).

\begin{tabular}{|c|c|c|c|c|}
\hline \multicolumn{5}{|c|}{$\begin{array}{c}\text { TABLE-4 } \\
\text { COMPOUNDS IN PRODUCT WITH LARGEST AREA }\end{array}$} \\
\hline No. & Peak & $\begin{array}{c}\text { Percentage } \\
\text { Area }(\%)\end{array}$ & $\begin{array}{l}\text { Compound Name } \\
\text { Possibility }\end{array}$ & $\begin{array}{l}\text { Number of } \\
\text { C Atoms }\end{array}$ \\
\hline 1. & 2 & 5,09 & Hexanol & 6 \\
\hline 2. & 4 & 5,13 & Heptane & 7 \\
\hline 3. & 5 & 4,01 & Heptane & 7 \\
\hline 4. & 10 & 6,69 & Octane & 8 \\
\hline 5. & 11 & 5,67 & Octane & 8 \\
\hline 6. & 15 & 6,30 & Nonane & 9 \\
\hline 7. & 17 & 6,98 & Nonane & 9 \\
\hline 8. & 24 & 5,89 & Decane & 10 \\
\hline 9. & 26 & 3,61 & Decane & 10 \\
\hline 10. & 30 & 4,85 & $\begin{array}{c}\text { Octyl } \\
\text { silicopropane }\end{array}$ & 11 \\
\hline 11. & 31 & 7,03 & $\begin{array}{c}\text { 6-Ethyl-2-methyl } \\
\text { decane }\end{array}$ & 12 \\
\hline Tot: & centage & 61,25 & & \\
\hline
\end{tabular}

Based on the results of GC-MS analysis it is reveals that compound formed from catalytic hydrocracking process of used palm oil using Cr-activated natural zeolite catalyst is a compound on which similar with gasoline on the number of total carbon atoms between 6-12. As a result, it can be known that $\mathrm{Cr}$-activated natural zeolite catalyst is effective and selective to forming the gasoline using crude palm oil as raw materials through hydrocracking catalystic process.

Physical properties of product: Product distilled catalytic cracking can be physically tested to determine the similarity between the character of the product by gasoline sold commercially. In this study, the resulting product was tested using ASTM method D-1298 (Specific Grafity), ASTM D 323 (Reid Vapour Pressure), ASTM D 130 (Copper Strip Corrotion) and IKU/5-4/TK (Distillasi ASTM) and the calculation of heating value. Characteristics testing of biogasoline can not be done thoroughly because of the limitations of the product.

This test can hopefully provide an overview of the physical properties of biogasoline compared to commercial gasoline. Comparison of the physical properties of gasoline and biogasoline are presented in Table-5. It showed that biogasoline generated in this study have similar physical properties of gasoline. So that further testing using bioasoline as fuel can be done to know the engine performance.

Conversion of used palm oil into biogasoline: Having characterized using GC-MS as well as the physical test to compare the product with a commercial gas density test, conducted to determine the effectiveness of the conversion of $\mathrm{Cr}$-activated natural zeolite catalyst. Obtained from the calculation was resulted a conversion as $76.44 \%$ and a yield as $23.25 \%$.

\section{Conclusion}

The catalyst, $\mathrm{Cr}$-actived natural zeolite is quite effective in the process of used palm cooking oil hydrocracking into biogasoline. The catalyst $\mathrm{Cr}$-actived natural zeolites have a higher surface area than the natural zeolite. Compounds that formed from used palm cooking oil through catalytic hydrocracking process on Cr-actived natural zeolite is a compound which almost similar to gasoline by the number of carbon atoms between 6-12. Biogasoline generated in this study has physical properties similar to premium gasoline.

\begin{tabular}{|c|c|c|c|c|c|}
\hline \multicolumn{6}{|c|}{$\begin{array}{c}\text { TABLE-5 } \\
\text { COMPARISON OF THE PHYSICAL PROPERTIES OF GASOLINE AND BIOGASOLINE }\end{array}$} \\
\hline No. & Type of Testing & Unit & Premium $88^{*}$ & Biogasoline $^{* *}$ & Test Methods \\
\hline 1 & Specific Grafity at $60 / 60^{\circ} \mathrm{F}$ & $\mathrm{kg} / \mathrm{m}^{3}$ & 715 & 739 & ASTM D 1298 \\
\hline 2 & Copper Strip Corrotion & - & $1 \mathrm{~A}$ & $1 \mathrm{~B}$ & ASTM D 130 \\
\hline 3 & Gross Heating Value & $\mathrm{Btu} / \mathrm{lb}$ & 19.800 & 20.255 & Calculated \\
\hline 4 & Reid Vapour Pressure & Кра & 62 & 61,9 & ASTM D 323 \\
\hline \multirow[t]{5}{*}{5} & Distillasi ASTM & & & & D 86/99a \\
\hline & $10 \%$ Vanor & ${ }^{\circ} \mathrm{C}$ & 74 & 52 & IKU/5.4/TK-01 \\
\hline & $50 \%$ Vapor & ${ }^{\circ} \mathrm{C}$ & 125 & 93 & \\
\hline & $90 \%$ Vapor & ${ }^{\circ} \mathrm{C}$ & 180 & 170 & \\
\hline & End Point & ${ }^{\circ} \mathrm{C}$ & 215 & 235 & \\
\hline
\end{tabular}




\section{ACKNOWLEDGEMENTS}

Financial supports from Directorate of Higher Education, Republic of Indonesia and Gadjah Mada University, Yogyakarta, Indonesia (Hibah Kerjasama Institusi 2013, Project No. LPPMUGM/1401/LIT/2013) are gratefully acknowledged.

\section{REFERENCES}

1. B. Argeur and F.G. Landolt, J. Catal., 11, 145 (1972).

2. P. Cao, A.Y. Tremblay, M.A. Dube' and K. Morse, Ind. Eng. Chem. Res., 46, 52 (2007).

3. B.C. Gates, I.R. Katzer and G.C.A. Schuit, Chemistry Catalytic Processes, McGraw Hill Book Co., New York (1979).

4. A. Wijanarko, D.A. Mawardi and M. Nasikin, Makara Technol., 10, 51 (2006).
5. K.V. Padmaja, N. Atheya and A.K. Bhatnagar, Biomass Bioenergy, 33, 1664 (2009).

6. S. Bhatia, A.R. Mohamed and N.A.A. Shah, Chem. Eng. J., 155, 347 (2009).

7. F.A.A. Twaiq, A.R. Mohamad and S. Bhatia, Fuel Process. Technol., 85, 1283 (2004).

8. B. Yoosuk, P. Udomsap, B. Puttasawat and P. Krasae, Bioresour. Technol., 101, 3784 (2010).

9. H. Sun, J.X. Han, Y.Q. Ding, W. Li, J.Z. Duan, P. Chen, H. Lou and X.M. Zheng, Appl. Catal. A, 390, 26 (2010).

10. J.X. Han, H. Sun, Y.Q. Ding, H. Lou and X.M. Zheng, Green Chem., 12, 463 (2010).

11. S. Bezergianni and A. Kalogianni, Bioresour. Technol., 100, 3927 (2009).

12. C.M.R. Prado and N.R. Antoniosi Filho, J. Anal. Appl. Pyrolysis, 86, 338 (2009). 